\author{
Marko Snoj \\ Inštitut za slovenski jezik Frana Ramovša ZRC SAZU, Ljubljana
}

\title{
Slovene Place Names with the Suffix -ina: Some Difficult Cases and Implications for South Slavic Onomastics
}

\begin{abstract}
Članek se osredotoča na slovenske in nekatere druge južnoslovanske zemljepisnoimenske družine, $\mathrm{v}$ katerih je krajevno ali pokrajinsko ime tvorjeno s pripono -ina, pripadajoča pridevnik in stanovniško ime pa sta tvorjena iz podstave brez nje. Na etimološko in razvojno jasnih primerih se ugotavlja tvorbeni model takih imenskih družin, ki lahko bistveno pripomore k rešitvi zapletenih problemov, kot sta slovensko Gameljne in srbsko Priština. Posega tudi v terminologijo imenoslovne stroke in predlaga, da bi se za imenske družine, v katerih pridevnik in/ali stanovniško ime nista tvorjena iz (celotne) osnove krajevnega imena, uporabljal izraz nekonsolidirane imenske družine.
\end{abstract}

The paper focuses on Slovene and certain other South Slavic geographical name families in which the local or regional name is formed with -ina and the corresponding adjective and ethnonym are formed from bases without this suffix. On the basis of transparent examples in terms of etymology and sound changes a word-formational process can be discerned which can be applied to solve more difficult cases, such as Slovene Gameljne and Serbian Priština. Furthermore, a terminological proposal for onomastic terminology is proposed, namely, that in instances where the adjective or ethnonym are not derived from the (whole) base of the place name, the term unconsolidated family of names be used.

The process of considering possible etymological solutions to a problem usually consists in positing assumptions and selecting the most plausible among them. ${ }^{1}$ In both processes, strict rules of historical and comparative linguistics must be applied. As additional arguments, all relevant facts and interpretations are allowed as long as they are used correctly and honestly. It is extremely important that a plausible etymological solution explains the formal part of a word as well as its content, that is, its semantic component or meaning. In positing and proving an etymological solution to a proper name we usually face the lack of an important criterion: in most cases we are not able to prove, or at least indicate the semantic component of a solution. A proper name is a word that has lost its meaning and has become a pure designation. Finding its erstwhile meaning is in fact its etymological solution. In contrast to etymological research of common nouns, appellatives, where formal and semantic arguments support each other, the etymological research of proper names - where the semantic component is yet to

${ }^{1}$ This paper was delivered in Banff on May Day 2008 at the 16th Balkan and South Slavic conference. A public lecture on this topic was also presented in the Linguistics Colloquy, co-sponsored by the Linguistics Department and the Department of Slavic Languages, University of Kansas, on 5 May 2008. 
be discovered - is akin to staging the Para-Olympics with the same standards as the Olympic Games themselves.

Could the task be more difficult? The answer is yes, particularly if we are treating Slovene onomastic material. Contemporary Slovene orthography is historically and etymologically oriented. Words are written - to simplify to the extent possible - as they were or would have been spoken in the 16th century in central Slovenia. The literary standard does not take into consideration most phonetic changes that the Slovene dialects and colloquial language have undergone thereafter. Among these changes one is of particular importance, that is, the modern vowel reduction. ${ }^{2}$ In almost all Slovene dialects an unstressed $i$ and $u$ (coming from an unstressed $i, \grave{e}$ and $u$ or syllabic $l$, respectively) merged with the reduced vowel $\partial$ and subsequently disappeared, or underwent other changes, that have been conditioned by dialectal factors and/or phonological environment. While we know from our 16th century Protestant writers and from comparison with material from other Slavic languages, how to write most inherited words correctly, the situation with respect to place names is significantly different. Most Slovene place names are not mentioned in 16th century Slovene ecclesiastic texts and are not included in Slovene texts until the 17th, 18th, or even 19th century. Before the mid-19th century, official names of Slovene places were only in German, and in some regions Italian or Hungarian. The standardization of Slovenian place names in the Slovene language that began in the first half of the 19th century thus could not follow the historical and etymological principle. Consequently, many Slovene place names have been standardized in approximate dialectal form or even hypercorrectly or misleadingly ${ }^{3}$ in some other way. The field records of Slovene place names on which they have become standardized had been made in the 19th century by Slovene intellectuals and students with rather weak linguistic skills. It is true that many Slovene place names have been recorded in medieval land registers, contracts and similar documents, written in Middle High German or Medieval Latin, but these data were in the 19th century yet to be discovered and explored. Once a place name obtained official status, it could hardly be changed, as tradition prevailed in the orthographic rules for historical and etymological writing. The result is that many Slovene place names with non-transparent etymologies have not been standardized applying the same orthographic rules as have been applied in the standardization of other words. Etymological research of a Slovene place name thus necessarily begins in the field.

Let us first examine a relatively simple case. In Styria near Celje there is a village named Ljubéčna. ${ }^{4}$ In the local dialect it is now pronounced lu'be:čna. ${ }^{5}$ Considering

${ }^{2}$ For sound changes in Slovene and its dialects mentioned here and henceforth see Greenberg 2000 .

${ }^{3}$ The standard form Višárje, basing on Upper Carniolan Ušà:rje gives the impression that the mountain name has been formed from vis(ok) 'high'. Upper Carniolan $u s$ - in anlaut can come from $v i \check{s}^{-}, v u \check{s}-, u \check{s}^{-}$, or $l u \check{s}^{-}$. The etymon of the name is Old Friulian Lussarie < Middle Latin Maria Luciaria, so the name should be standardized correctly as Lušarje, as it was written by Prešeren in the 19th century.

${ }^{4}$ Slovene place names in the standardized form here and henceforth are adduced according to Jakopin et al. 1985.

${ }^{5}$ The field note was kindly provided by Tjaša Jakop. 
medieval records with the form an der Lubiczen from the years 1436 and $1445,{ }^{6}$ it is evident that the stressed vowel was an $i$ and not $e$ and that there was a vowel between the $\check{c}$ and $n$. The only possible reconstruction of the place name is therefore *Ljubičina and that should be its correctly standardized form. The contemporary official rendering Ljubéčna has been based on an mistaken assumption, that is, that the dialectal long $e$ : arose from a long $\bar{e}$ and not from a long $\bar{l},{ }^{7}$ and that the name has been formed with the suffix -bna with a yer instead of -ina, as shown in the medieval record. If we knew the name only in the standard form, we could not set the correct etymology. On the other hand, the knowledge of older records leads to a reasonable etymological conclusion: *Ljubićina has been formed from a personal name Ljubič that has been preserved in the contemporary Slovene surname Ljubič. The function of the suffix -ina is - as I intend to show later-expressing the property or the place of dwelling. Thus, the primary meaning of the place name Ljubéčna $<*$ Ljubičina is 'Ljubič's property' or 'Ljubič's dwelling'.

A similar case is the place name (Mála, Vélika) Ráčna in Lower Carniola, which was recorded in 1458 as Raditschin. The correctly standardized form would be spelled * Rádičina. The contemporary name has undergone the loss of two unstressed $i$-sounds and assimilation of the dental $d$ before $\check{c}$. It has been formed from the personal name Radič, which has been preserved as a surname. The primary meaning of the place name was 'Radič's property' or 'Radič's dwelling'. As Ljubič is the patronymic of the personal name Ljubo, so is Radič the patronymic of the personal name Rado.

The original forms and semantic contents of the aforementioned place names have been obscured because of the dialectal development after the 16th century. The fact that the personal names * $L$ 'ubít' $b$ and * Rädit'b belonged to the accent type $a$ results in the circumstance in which the vowel $i$ of the suffix -ina must have been lost. The same applies to the place names Slávina and Svétina, originating from the personal names Slavo and Svet, in which, however, the vowel $i$ of the suffix has been preserved in the standardized form, although it has been regularly lost in the local dialects. If the personal name belonged to accent types $b$ or $c$, the $i$ of the suffix has been stressed and therefore preserved. Thus, the Prekmurje place name Bogojína can be explained as 'Bogoj's dwelling or property' and the place name Krtina, which appears once in Upper and once in Lower Carniola, can be explained as 'Krt's dwelling or property'. The nickname $K r t$, still known as a surname, originates from the common noun krt of the accent type $b$, meaning 'mole'. The same applies to the place name Savina from older *Sovina ${ }^{8}$ with primary meaning 'Sova's dwelling or property', which has been

${ }^{6}$ For medieval records of Slovene geographical names here and henceforth see Kos 1975 and Blaznik 1986-89.

${ }^{7}$ Ljubečna lies on the border between the Central Savinja and Central Styrian dialects. The reflex $e$ : from $\bar{l}$ is basically Central Styrian, where reflexes of long $\bar{e}$ and $\bar{l}$ merged into the diphthongal $e i$. The monophthongal $e$ : is however an infiltration from the Central Savinja area, where it is a regular reflex of a long $\bar{e}$, but not $\bar{l}$ (for details see Ramovš 1935: 157, 161, 162, Greenberg 2000: 177).

${ }^{8}$ The military map of 1763-87 mentions the area as Sovenfki verh, see Rajšp 1999: Karte 162, section 1B. In the description of the map, the location is known as Sovenshki Verh (Rajšp 1999: Opisi 33). In the local dialect sporadic pretonic akanje has been noted, cf. ła'på:ta< 
formed from the personal name Sova, still known as a surname, originating from the common noun sova 'owl' of the accent type $b$.

While the place names Krtína, Savina, Slávina, and Svétina have been formed directly from personal names, there are more cases, in which the suffix -ina has been added to adjectival stems. In the Vipava valley there is a place called Ajdovšcina that has been formed from the adjective ájdovski, belonging to the appellative ájd 'pagan', itself a loanword via German and Gothic from Greek. The name Ajjovščina can be explained as 'a place where pagans used to live', referring to excavations from Roman times. In south-west Slovenia there is a place called Márkovščina, which has been formed the same way from the personal name Márko. The name was first mentioned 1694 as Marcouschena.

Some of the place names formed from adjectival stems lack obvious explanation. The place name Skarúčna has been standardized in the local pronunciation of Upper Carniola. In this dialect pretonic akanje has been recorded and the modern vowel reduction took place. The record Schkorucina from the year 1444 clearly shows that the contemporary name arose from *Skorúcina, which can be explained as a derivation with the suffix -ina from the possessive adjective *Skorüt'b, belonging to the personal name *Skorütb. The primary meaning and thus the etymological explanation of the place name Skarúčna is therefore recognized as 'Skorut's property' or 'Skorut's dwelling'. Technically, this explanation meets all standards of contemporary etymology. The only problem remaining is that the name *Skorüts has not been attested. In order to establish grounds for its former existence, one can assume that this name has been formed from the personal name Skoroslavb, still known in Serbia, just as the well-known personal name Borutb has been formed from Borislavъ. ${ }^{9}$

We can observe the survival of an ancient Slavic personal name also in the Lower Carniolan place name Stíčna, that has been first recorded 1689 as (in der Land-Sprache) Sitizena.$^{10}$ The record should be read *Žitíčona, that is *Žitícina, that regularly gave *Štična, from which the modern spelling Stíčna arose by dissimilation. The primary *Žitićina has been explained as a collective derivation of the personal name *Žitič, meaning 'Žitič's people'. In our interpretation, it could also be 'Žitič's dwelling or property'. The personal name *Žitič has been lost in Slovene, yet it has been preserved in Croatian as a surname Žitić. It is a patronymic of a hypochoristic *Žitz, belonging to the compound personal names *Žitigojb, ${ }^{*} \check{Z}$ itomirz, or *Žitoradb. ${ }^{11}$

A place name does not "live" by itself. It has its family that consists at least of the adjective and the ethnonym in both natural genders. It is a fallacy to consider a place name as the head of the family, the patriarch in the biblical sense, or pater

*lopăta (Weiss 2001: 334). The erstwhile name *Sovina is indicated also by the surname Sovinšek $<*$ Sovinščak.

${ }^{9}$ The etymology of the place name Skaručna has been solved by Ramovš 1952/53: 739 . Bezlaj's explanation is incorrect (1995: 241).

${ }^{10}$ This record, originating from Valvasor's Die Ehre des Herzogtums Krain (XI, 530) quoted by Ramovš 1924: 266.

${ }^{11}$ The etymology of the place name Stična has been solved by Ramovš 1924: 266. 
familias from the Roman times, from whom all other members of the family issue. The language tends to establish the order in place-name families by recognizing a place name as the basis, but it does not manage to do so in all cases. There are many place names in the Slavic world that have failed to give birth to the corresponding adjectives and ethnonyms, but that have been formed from the same ancestor. For instance, the Croatian place name Dùbrōvnīk has been formed from the same basis *dobrova "forest" as has its former ethnonym *Dubrovac, from which the adjective dùbrovački has been derived. A similar case is the Croatian place name Š̈̈benīk with the adjective šỉbēnskī. With the exception of Bogojína, Krtína, Slávina, Savina, and Svétina, all the previously discussed Slovene place names belong to families of names in which the adjective and ethnonym have not been formed from the place name itself, although they have a common ancestor. Let us call such derivational nests unconsolidated families of names. ${ }^{12}$ To Ljubéćna $<*$ Lubiltina belong the adjective ljubéški<*l'ubït'bskъjъ and the ethnonym Ljubéčan <*Lubïtan(e). All three members of the family are brothers, formed with appropriate suffixes from the personal name Ljubič $<*$ Lubilt'b. The same applies to the family Skarúčna $<*$ Skorütina with its adjective skarúški < *skorüt'bskbjb and ethnonym Skarúčan < *Skorütan(e), or to the family Stíčna $<*$ Zitîtina with its adjective stišsi $<*$ žitít'bskъjb and ethnonym Stíčan < *Žitḯan(e). The place names Ájdovščina and Márkovščina indicate a more complex situation. They have been formed from the adjectives ájdovski and márkovski, respectively, which are still in use. The adjectives ájdovski and márkovski have been formed from the possessive adjectives ájdov and Márkov, from which the ethnonyms Ájdovec and Márkovec have been formed. In relationship terms, the place names Ájdovščina and Márkovščina are sons of the corresponding adjectives ájdovski and márkovski, respectively, and nephews of the ethnonyms Ajdovec and Márkovec, respectively. An even more curious family situation is found in the case of Ráčna, to which the adjective rádenski and the ethnonym Rádenec belong. While Ráčna, arising from *Rádičina, was named after Rádič, who was obviously a son of Rádo, the adjective rádenski preserves the father's name Rádo. In relationship terms, Ráčna is a cousin of rádenski. It seems plausible to assume that a man with the name Rado established the settlement and that the settlement at his time had been named *Radna vas or something similar, from which the adjective rádenski had been regularly formed. After Rado's death, his son Radič inherited the land and the settlement took the name * Rádičina after its new owner. However, the adjective and the ethnonym did not follow the change of the ownership. They remained the same, still pointing to the original owner Rádo.

${ }^{12}$ Such families of names have not been termed so far and have not been discussed in manuals in which one would expect such a discussion, e.g., Srámek 1999. The term family of names itself is hard to define properly, as adjectives are not names and since in some languages, in East Slavic, Bulgarian, and some others, ethnonyms are not considered names. More precisely, we should speak about families of names and other relative words. Let us make use of a metaphor, considering names as the aristocrats among words. While in normal, consolidated families of names, all members - either noble or common - descend from the noble place name, the situation in unconsolidated families is different: the noble place name is not the father of (all) other family members, it can be either their brother, son, or an even more distant relative. 
Understanding the formation process of unconsolidated families of names is of great importance for establishing etymological proposals of some opaque place names. Let us put the place name Gámeljne under the microscope,${ }^{13}$ to which the adjective gámeljski and the ethnonym Gámeljc are in use in the contemporary language. Since the middle ages, the village Gámeljne near Ljubljana has been divided into three settlements, Zgórnje, Srédnje, and Spódnje Gámeljne. The fact that the name is a plurale tantum could be connected with this division, yet it is not the only possibility and for etymological purposes this syntactic feature plays no crucial role. ${ }^{14}$ The village was first mentioned in the year 1260 as Gemlein in a Middle High German text. In this record, the German umlaut of the root vowel and the German diphthongization of suffixal formant long $\bar{l}$ can be recognized. The original Slovene form of the place name must therefore have been * Gámljine, from which the contemporary local $\gamma a$ ámalne regularly developed after modern vowel reduction. The contemporary adjective gámeljski and the ethnonym Gámeljc, showing no trace of the suffix -ina,${ }^{15}$ must have been formed not from the place name itself, but from their common basis. As the place name Skarúčna has been formed from the possessive adjective *Skorüt'b, belonging to the personal name *Skorüt , so the place name * Gámljina must have been formed from the possessive adjective * Gäml'b, belonging to the personal name *Gämb. This personal name has been preserved in Old Russian Gamb, in the Slovene surname Gam, and its patronymics, Croatian Gamić and Russian Gámov. The place name Gámeljne, which should be correctly standardized

${ }^{13}$ The recent discussion of the place name Gameljne in Torkar 2006: 175-176 is in my view incorrect. The author derives the name from Middle High German Gamlin, in which he sees the loan name from a Slovene creek name * Kamič (or *Kamec), in which Slavic diminutive suffix is thought to be replaced by the Middle High German -linn. Against this proposal the following arguments may be enumerated. (1) The broader area of Gameljne has never been colonized by the Germans, so one would not expect that the German impact on the organic Slovene dialect would be strong enough to change the name of the settlement. (2) The supposed diminutive form suggests that there were two creeks, ${ }^{*}$ Kam and smaller/shorter * Kamic $\left(\right.$ or ${ }^{*}$ Kamec) . However, there is only one creek with the contemporary name Gámeljščica that flows through the settlement. (3) The creek Gameljščica is not a gravel-bedded, but rather a silty creek, so the attempt to explain Gameljne via German from the same basis as Slavic *kämy 'stone' from the motivational point of view does not seem probable.

${ }^{14} \mathrm{Cf}$. the plural place name Máline, denoting an undivided small village in Bela Krajina. It seems likely that this name has been derived from the nickname Mali 'the small one' (cf. German surname Schmall, English Small).

${ }_{15}$ Since the final $-n$ drops out in dialectal Gen. Pl. iz yà:məl = standard iz Gámeljn, it would be also possible to derive the adjective gámeljski and the ethnonym Gámeljc phonetically from the forms with -(i)n-. However, this assumption seems rather unlikely in view of the adjective $\check{s} m a ́ r s k i<* \check{s} m a ́ r t s k i<*$ *śmártəsk instead of $* \check{s} m a ́ r t ə n s k ə<*$ šmártinski, belonging to the name of neighboring village Šmártno (standardized hypercorrectly) $<* S ̌$ (ent)-Mártin. This adjective, in which $-n$ - of the saint's name elided irregularly, becomes clear only after the model *Gámline $>$ *Gáml’ane - *gáml’aska at the beginning of the modern vowel reduction, before the loss of the semivowels. The model could only work at the stage *Gáml'ane

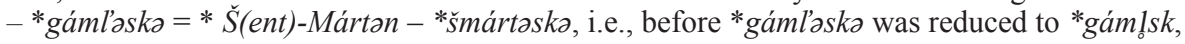
from which the attested $\gamma a$ : molsk issues. This is the evidence that the adjective once was in fact *gáml’aska $<*$ gäml’bskbjb and not**gáml’anskə<**gäml’inbskъjb. The point is that the loss of -n- would not be expected until **gáml’anska had developed into **gámlinsk. 
as Gámljine, is etymologically explained as 'Gam's settlements'. The formation of the adjective gámeljski and the ethnonym Gámeljc is comparable to rádenski and Rádenec. Both are formed from adjectival basis *Gaml'b or *Radbnz, respectively, which were formed with different suffixes from different personal names.

The lack of the place-name-forming suffix -ina in the adjective and the ethnonym doubtlessly leads to the recognition that all names of the derivational nest must have been formed within the process of proper name formation and not the formation of common nouns. As we have seen from the examples discussed, the Slavic suffix -ina of place names can be added either on substantival or adjectival basis. In unconsolidated families of names the root morpheme as a rule denotes a person, usually a personal name or its possessive adjective. It seems likely that adding the suffix -ina to substantival bases originally resulted in collective names, and that adding the same suffix to possessive adjectival bases resulted in names of properties.

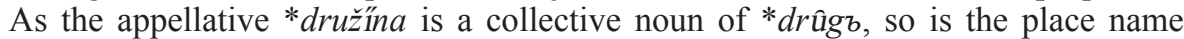
Svétina a collective name of the personal name Svet. While the structural meaning of *družîna can be recognized as 'companions', the structural meaning of Svétina can be recognized as 'the Svets', that is, 'Svet and his people'. This assumption is supported by the local place name Svétje, which is also in use instead of the name Svétina. The

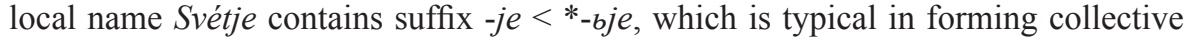
nouns. The same derivational relation is found between Croatian and Slovene names of river basins. The Croatian name of the Drava basin is Podravina, and the Slovene form is Podrávje. On the other hand, the place name Skarúčna $<*$ Skorütina derives from the possessive adjective *Skorüt'b, formed from the personal name *Skorütb. The derivational and semantic relation between the basic possessive adjective and place name matches the relation between the adjective *bélb and its abstract noun *bělinä. As whiteness is structurally 'the state of being white', so *Skorütina is structurally 'the state of being the property of Skorut', whereby the additional component of property has already been included in the basic adjective. According to this definition, place names like Krtína, Savína, Slávina originally meant 'Krt and his people', 'Sova and his people', 'Slavo and his people', respectively, while the place name Gámeljne originally denoted 'Gam's property'. A problem is presented by the circumstance that substantival stems ending in palatal consonants do not differ from their possessive adjectives if the adjectives have been formed with the suffix $*_{-j}$. The names *Rádičina $>$ Ráčna and *Žitícina $>$ Stíčna can be formed either from the personal names *Rädit’b or *Žitït'b, or from their homophonic possessive adjectives. In Slovenia no place name in -ina with an unconsolidated adjective and ethnonym has been found that have been unequivocally derived from a substantival base. Such cases seem to be Croatian Moslavina with its ethnonym Moslavac, and Serbian Vojvodina with its ethnonym Vòjvođanin and adjective vòjvođanski. However, they are not certain, since Mòslavina would be expected to have arisen from *Moslavovina by haplology, ${ }^{16}$ and Vojvodina from *Vojevodinina, again by haplology, ${ }^{17}$ whereby $-o v$ - and -in- are adjectival suffixes.

${ }^{16}$ The developement Mòslavina from *Mojslavovina is assumed by Skok 1954: 37.

${ }^{17}$ The expected univerbization result of (zemlja) voj(e)vodina would be *Voj(e)vodinina, from which Vojvodina developed by haplology. 
If, for instance, the place name *Zitíčina $>$ Stíčna had been formed from the adjectival stem * Žitič, the primary meaning of the place name would not be 'Žitič and his people', but 'Žitič's property'. The place names *Gámljina and *Žitíčina are thus most likely products of univerbization from original *Gamlja vas and *Žitiča vas, respectively. The place names formed from non-possessive adjectives, such as Ájdovščina and Márkovščina, are also results of the univerbization of former Ajdovska and Márkovska vás, respectively. These adjectives, although formed from possessives, denote characteristics that are expressed in the base. Ajdovščina was originally 'the place where pagans lived', and Márkovščina 'the place with the church consecrated to Saint Mark'. Although possibly the differences in the primary structural meaning can be important for other purposes, they are not incorporated in the present paper. For etymological purposes, it does not make a substantial difference, if, for instance, *Žitićina > Stična is explained as 'Žitič and his people', 'Žitič's dwelling', or 'Žitič's property'. In either case there was a man with the name Žitič who gave the name to the settlement, whether he was a father of a family, dweller, owner, or-most probably - all three at once. ${ }^{18}$

In Slovenia many families of names are noted in which the suffix -ina of a place name lacks in the corresponding adjectives and ethnonyms. It is not my intention to present and to discuss all of them, but only two more. (1) To the place name Ljubgôjna, which arose from *Ljubigojina, as seen in the record Lvblogoyn from the year 1303, the adjective ljubgôjski, and the ethnonym Ljubgôjec are in use, both formed directly from the Slavic personal name *L'ubigojb. (2) To the place name Láhovna, which arose from *Láhovina, as seen in the record Lachowinn from year 1436, the adjective láhovški is in use, while the ethnonym Láhovenčan has already taken the stem of the place name. The basis of this derivational nest is the original ethnonym Lah, denoting a Roman speaking aboriginal, which has been preserved in the surname $L a h$, and in several geographical names, such as Láško, Lášče, Láhinja and many others. However, unconsolidated families of names represent a quite weak system and the language tends toward consolidation of its members in favor of the stem of the place name, as has already been seen in the case of the ethnonym Láhovenčan instead of the expected *Láhovčan. In many cases, the adjective and the ethnonym have been gradually totally adjusted to the place name, as for instance in case of the place name Dragočájna $<*$ Dragočajina, formed from the Slavic personal name *Dragočajb, to which the adjective dragočájenski and the ethnonym Dragočájenec are in use. We can only assume that the adjective once was *dragočajski and that the ethnonym once was *Dragočajec.

Not all Slovene place names on -ina derive from designation of a person or a personal name. Some of them arose by direct onomization from appellatives, such as Planina from the appellative planina 'treeless, open place', or Dolina from dolina 'valley'. In contrast to the previously discussed cases, all families in which the place name in -ina arose by direct onomization from appellatives are consolidated. To the

${ }^{18}$ S. M. Dickey (p. c.) suggests that the suffix -ina in place names with a personal name basis denotes a large family, zadruga; so Krtina would be explained as 'Krt's zadruga' and Stična as 'Žitič's zadruga'. 
place name Planina belong the adjective planinski and ethnonym Planinec, and to the place name Dolina belong dolínski and Dolínec.

From the discussion hitherto we can conclude that place names in -ina with unconsolidated name families could arise neither by direct onomization of appellatives, nor could they be formed with the suffix -ina from appellative bases. The function of the suffix -ina of these names is to create a place name from an adjectival base that had already been a part of the place name: *Gámljina from *Gamlja vas, Ajjovščina from *Ajdovska vas. The consolidated name families could arise either by direct onomization of appellatives on -ina (Planina), or have been formed with the suffix -ina from a substantival basis, either appellative (Vrbina), or of a personal name (Svétina).

The only exceptions to this rule are rare cases in which the family of names appears unconsolidated only at first blush. Such a rare case is the place name Ópčine near Trieste with the adjective ópenski and the ethnonym Ópenec. The basis can be seen in the Slavic appellative * obbt' ina 'common piece of land', which in the Karst dialect yielded *'uopkina. The dialectal name 'uopkine arose from this appellative by pluralization. The regularly formed adjective *obstinbskzjb yielded in the Karst dialect $*$ òt'inski, after the modern vowel reduction *opt'nski, in which $t$ ' first lost its palatal component (as in southern Inner Carniolan'svetnca 'Candlemass') and dropped out in its further development, as in 'mesnu from mastno 'fatty'. ${ }^{19}$ Another case is the place name $\breve{S} i s ̌ k a$, now denoting a part of northern Ljubljana, to which the adjective š́š́enski and ethnonym Š́šskar are in use, all with the long falling pitch: $\check{s} \imath$ : $\check{s}$-. The name arose by assimilation from Hiška (cf. 1308 ze Cheis), which is obviously a diminutive from hiša 'house' $<* x y$ šs $a$. The seemingly unconsolidated adjective šišenski regularly arose from šišščnski $<* x y$ y̌ščbnbskъjb.

Unconsolidated families of names are limited neither to place names with the suffix -ina, nor to the Slovene territory. In Slovenia they are found also in some names with the suffix -ica, which has partly the same function as the suffix -ina. In Bela Krajina there is a place Rádovica, where in the local dialect adjective rádovski and ethnonym Rádovec are in use. The same structural type is noted in the Upper Carniolan place name Stahôvica with the local adjective stahôvski, where, however, the ethnonym Stahovičan has already been consolidated to the place name.

A similar case is the Serbian place name (Sremska) Mitrovica, to which the adjective mïtrovačk $\bar{\imath}$ has been formed from the former ethnonym *Mitrovac, based on the possessive adjective Mitrov from the personal name Mitar $<$ Dmïtar, itself

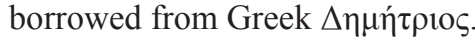

Our discussion is, however, limited to names with the suffix -ina. In Croatia we find a place name Mòslavina (supposedly from *Mojslavovina) with the ethnonym Moslavac and the adjective mòslavački. The same pattern is found in the name of the southern part of Bosnia and Herzegovina: the name of the territory is (in standard Croatian) Hèrcegovina, an inhabitant is Hèrcegovac and the adjective is hèrcegovački . The former name has been formed from the (possessive adjective of the) Slavic

\footnotetext{
${ }^{19}$ Rigler 1963: 169.
} 
personal name Mojslav, still known among the Serbs, the latter from the possessive adjective of the appellative hèrceg 'duke', which has been borrowed via Hungarian from German Herzog.

There are, of course, many more consolidated than unconsolidated name families in other regions of the South Slavic territory, for example: with regard to the Croatian place name Vivodina the adjective vivodinski and the ethnonym Vivodinac are in use, and to the Bosnian place name Bïjeljina belong the adjective bjēljīnski. The former name has been formed either directly from the dialectal reflex of the Slavic appellative *vojevoda 'duke', or the anthroponym, that arose from this appellative by onomization (compare the Slovene and Croatian surname Vivoda), the latter from the possessive adjective *Bèl'b, which belonged to the nickname *Bélb(jb) with the primary meaning '(the) white one, (the) pale one', still known in the patronymic surnames Croatian Bijelić, Slovene Belič.

An important name with unconsolidated family is the name of the capital of Kosovo. In the local Serbian dialect it is pronounced Prîstina, the corresponding adjective is prištêvskī, and the ethnonym is Prištèvac, attested as early as the 15th century. ${ }^{20}$ The ethnonym has been known in Serbian also as the surname Prištevac. The name Prištêvka bears not only a feminine resident of Prishtina, but also the creek that flows through the city. Although the suggested etymological explanation, namely the correspondence between the place name and the Moravian Czech appellative prýščina, meaning 'a spring of water, flooded spot on the field', ${ }^{21}$ seems to be a perfect match, it is methodologically untenable to derive the place name by direct onomization from this appellative, since we have learned from the above discussion that the suffix -ina in place names with unconsolidated adjectives and ethnonyms could only be added in order to create a place name from an adjective which is formed from designation of a person-either an appellative or proper name. Furthermore, if the name arose by direct onomization from the appellative *pryšcìna, one would expect the stress on the penultimate syllable in the local Serbian dialect of Kosovo. The fact that the adjective prištêvski and ethnonym Prišstëvac have not been formed from the place name, but from its basis, represents a guarantee that the derivational nest has been formed in Slavic. The name Prî̌tina could not be of Illyrian, Albanian ${ }^{22}$ or Romance ${ }^{23}$ origin, as has also been suggested. If the name Prîstina were not of Slavic origin, one would expect the adjective prîstinski in the local dialect, not only in standard Serbian, where it is clearly secondary. Since the suggested Romance form *Prīsciāna (Proto-Romanian *Priştînă) must had been stressed on the penultimate

${ }^{20}$ Daničić 1863: 446 quotes poslaxb ovuzi knigu po prišteštevcu and adds "koje je pogrješka mjesto prištevcu."

${ }^{21}$ Maretić 1952: 179.

${ }^{22}$ Gashi (1976: 123) thinks that the name Prishtina issues from Illyrian Aristina, Aristinum, yet he fails to quote the source for the supposedly Illyrian names. Hamp (2007 Shtesë: 1) derives it from Indo-European *prrt- 'ford' with the typical Albanian reflex $r i<r$ (from the same basis he derives also Prizren) + *stein $\bar{a}$ 'lot of stones'. However, since the word for 'ford' was a proterokinetic abstract noun on *-tu-/-téu- (Latin portus, Old Norse fjorðr), one would expect that at least the $-t$ - of the suffix would be preserved in both Albanian names.

${ }^{23}$ Loma (1997: 3-4) argues for the Roman origin. 
syllable, there would also be no reason for the accent shift, which could yield the attested Prîstina. The Albanian stress Prishtína tells nothing about the primary accent conditions, since - according to Albanian accent rules - all Albanian words in -ina bear the stress on the penultima, even if they are borrowed from a differently stressed source, as for instance in the place name Sllatina, that was certainly borrowed from the Serbian Slätina. The assumption that the name Prîstina is of Slavic origin is supported by at least three more pieces of circumstantial evidence.

1. The vast majority of the place names in Kosovo are of Slavic origin.

2. The place name Prîstina occurs not only in Kosovo. The same name designates a village in Bosnia near Banja Luka.

3. The same formational basis can be seen in the name of the Zlatibor river Prištevica, which has most likely been derived by univerbization from *Prišteva reka.

Typologically, the basis of the name under discussion could be either a designation of a person, a personal name, or - most likely — its possessive adjective. With regard to the Štokavian accent, it must have been pronounced in proto-Stokavian *prišč- or *prišć- with accent type $b$ (cf. the same accent pattern in the Kosovo place-name Sköčina, derivated from appellative*skòkъ or anthroponym *Skòkъ). The only appellative that fits phonetically is Slavic *prýščb, Serbian prîšt, attested also in some other Slavic languages. However, its meaning in all attested languages is only 'pimple, skin abscess', which could hardly be imagined as a semantic contents of a personal name. I am unaware of any personal name, not even a long-lasting nickname, arising by direct onomization from an appellative, meaning 'pimple or similar eruption of the skin'. An assumption that the basis of the name Prîstina would be the appellative *prýšč in the unattested sense 'spring of water', which could have yielded the Moravian Czech augmentative prýščina (although this appellative is more likely a deverbative from *prýskati 'spring, jet, splash', as are the place names Slovene Plúžna, first recorded 1257 as Plusina, and Serbian Plüžina deverbatives from *pluzziti), fails on a typological argument. To the best of my knowledge, there are no unconsolidated families of names in Slavic in which the place name would contain the suffix -ina and the basis would be a geographical term. So, semantic and typological arguments allow this appellative to be ruled out of further consideration. Since no Slavic appellative can be recognized as a base, the etymon should be sought within personal names. The number of phonetically possible reconstructions of the base that could yield the attested derivational nest is exactly 16. These are *Prist'b, *Prýst b, *Príščb, *Prýščb, *Prístbčb, *Prýstbčb, *Príšsčb, *Prýšbčb, *Príščcčb, *Prýščcčb, *Prístbcb, *Prýstbcb, *Príšbcb, *Prýšbcb, *Príščbcb, and *Prýščcbcb. The former 10 reconstructions could be either substantival or adjectival, the latter 6 could only be substantival. We have seen that Slovene and Croatian place names in -ina with unconsolidated adjective and ethnonym have much more often (if not always) been formed from adjectival than from substantival stems. Therefore it seems very likely also for the name Prîština that its basis represents a possessive adjective, formed with the Common Slavic suffix $*_{-j b}<$ Indo-European $*_{-i}$ - - . Considering this assumption, the number of possible substantival bases emerges for another 10 
possibilities: *Prístъ, *Prýstъ, *Priskъ, *Prýskъ, *Prístъkъ, *Prýstъkъ, *Príšbkb, *Prýšbkb, *Príšč $k b$, and ${ }^{*}$ Prýšč $b k$. After setting out the possibilities we must find convincing arguments for choosing the right one, or at least reduce their number to a minimum. The right way to do so is to inspect personal names with the right phonetic match known in the Balkans or in the other Slavic languages.

1. It is possible to assume that the derivational nest in question had been based on the anthroponym that has been preserved in the Croatian surnames Prišč and Prišć. In my opinion this personal name originates most likely from the Latin Nomen gentile Prīscius, which was formed from the first name Prīscus. For the derivational nest in question it would be plausible to derive it not directly from the personal name * Priščb but from its homophonic possessive adjective. It is also possible to derive it from a Slavic possessive adjective ${ }^{*}$ Priščcb, which could be seen as a formation from the unattested personal name ${ }^{*}$ Priskb, recognized in the patronymic Croatian surname Priskic,${ }^{24}$ which would have been borrowed from Latin first name Prīscus.

2. A more likely assumption is that the derivational nest under discussion had been based on a possessive adjective $*$ Príščc , formed from the personal name *Prišbkb, which has been preserved in the Kajkavian surname Prišek, in the Old Polish personal name Przyszek, and in the Polish surname Przyszek. This name is most likely a patronymic of the personal name ${ }^{*}$ Prišb, preserved as a surname in Polish Przysz and Sorbian Priš. It can be seen as a hypochoristic of the Slavic personal name Pribyslavb. The connection with this personal name can be confirmed by the Sorbian surnames Pribš and Pśibš, in which the sound $b$ of the supposedly basic personal name has been preserved. ${ }^{25}$

Given the possibilities, we can conclude the following: 1 . The formation of the name, adjective, and ethnonym are typically Slavic, showing a similar, yet not identical, structural type to some derivational nests in the northern part of the South Slavic area. The main difference lies in the (additional) possessive sufix -ov-/-ev- of the adjective prištêvski, which has been added for unclear reasons. 2. Considering the typology of the etymologically clear derivational nests in which only the place name contains the suffix -ina, the basis should be a possessive adjective of a personal name, which could be recognized either as a borrowed name from Romance Prisscus, Prīscius, or the patronymic *Prišsk $k$ of the hypochoristic *Prišs from the well-known Slavic personal name Pribyslavz.

\section{References}

Bezlaj, F. 1995. Etimološki slovar slovenskega jezika. Tretja knjiga P-S. Ljubljana. Blaznik, P. 1986-89. Historična topografija slovenske Štajerske in jugoslovanskega dela Koroške do leta 1500. Maribor.

Daničić, Đ. 1863. Rječnik iz književnih starina srpskih. Dio drugi. Beograd.

${ }^{24}$ The lack of palatalization is known also in other surnames, cf. Vukić, Markić, Brkić.

${ }^{25}$ The West Slavic material is quoted and explained by Rymut 1991: 224 and Wenzel 1992: 59. 
Gashi, S. 1976. La toponymie antique et la problème de l'autochtonie des Albanais. Onomastica Jugoslavica 6, 115-125. Zagreb.

Greenberg, M. L. 2000. A Historical Phonology of the Slovene Language. Heidelberg.

Hamp, E. P. 2007. Studime krahasuese për shqipen. Përgatiti dhe redaktoi R. Ismajli. Prishtina.

Jakopin, F., Korošec, T., Logar, T., Rigler, J., Savnik, R., and Suhadolnik, S. 1985. Slovenska krajevna imena. Ljubljana.

Kos, M. 1975. Gradivo za historično topografijo Slovenije (za Kranjsko do leta 1500). Ljubljana.

Loma, A. 1997. Srpskohrvatska geografska imena na -ina, mn. -ine: pregled tipova i problemi klasifikacije. Onomatološki prilozi 13, 1-26. Beograd.

Rajšp, V. 1999. Slovenija na vojaškem zemljevidu 1763-1787. 5. zvezek. Ljubljana.

Ramovš, F. 1924. Historična gramatika slovenskega jezika. II. Konzonantizem. Ljubljana.

Ramovš, F. 1935. Historična gramatika slovenskega jezika. VII. Dialekti. Ljubljana.

Ramovš, F. 1952/53. Iz slovenske toponomastike. Zgodovinski časopis 1952/53, 154-158. Reprinted in Zbrano delo II, 737-741. Ljubljana 1997.

Rigler, J. 1963. Južnonotranjski govori. Ljubljana.

Rymut, K. 1991. Nazwiska Polakóv. Wrocław, Warszawa, Kraków.

Skok, P. 1954. Pridjevske izvedenice od geografskih naziva. Jezik III/2, 34-37. Zagreb.

Šrámek, R. 1999. Úvod do obecné onomastiky. Brno.

Torkar, S. 2006. O domnevnem in dejanskem vplivu nemščine na podobo slovenskih zemljepisnih imen Landol, Runtole, Tacen, Gameljne. Wiener slavistisches Jahrbuch 52, 171-178. Wien.

Weiss, P. 2001. Fonološki opis govora kraja Spodnje Kraše (SLA 314). Jezikoslovni zapiski VII/1-2, 321-347. Ljubljana.

Wenzel, W. 1992. Studien zu sorbischen Personennamen. Teil II/2. Historischetymologisches Wörterbuch. Bautzen.

Prispelo julija 2008, sprejeto septembra 2008

Received July 2008, accepted September 2008

\section{Slovenska krajevna imena na -ina: nekaj težavnih primerov in njihov pomen za južnoslovansko onomastiko}

Članek obravnava slovenska in nekatera druga južnoslovanska krajevna in pokrajinska imena s pripono -ina, h katerim spadajo pridevniki in stanovniška imena brez te pripone, npr. sloven. Ljubéčna $<*$ Ljubičina s pridevnikom ljubéški $<* l j u b i s ̌ k i$ in stanovniškim imenom Ljubéčan $<*$ Ljubičan, hrv. Hèrcegovina s pridevnikom hèrcegovački in stanovniškim imenom Hèrcegovac. Za take imenske družine, ki doslej terminološko še niso bile opredeljene, se predlaga izraz nekonsolidirane imenske družine. Medtem ko so krajevna in pokrajinska imena na -ina v običajnih, konsolidiranih imenskih družinah lahko apelativnega nastanka, npr. Dolína, Planína, 
ali tvorjena iz osebnih imen, npr. Svétina, Bogojína, Krtína, Dragočájna, izgleda, da so imena na -ina iz nekonsolidiranih imenskih družin lahko tvorjena le iz svojilnih pridevnikov iz osebnih imen, npr. Ljubéčna $<*$ Ljubićina $<*$ Lubîtina iz *Lubït'b, ali besed, ki označujejo človeka, npr. Ájdovščina iz ájd 'pogan'. S precejšnjo mero gotovosti je mogoče domnevati, da so ta imena nastala po univerbizaciji dvočlenskih imen tipa *Ljubića vás, *Ajjovska vás, da so torej tvorjena iz osnov, ki so bile že deli imen, podobno kot so imena na -ica s pridevniško podstavo in nekonsolidirano družino nastala po univerbizaciji iz zvez tipa * Rádova vás $>$ Rádovica.

Pripadajoči pridevniki (ljubéški, ájdovski, rádovski) in stanovniška imena (Ljubéćan, Ajdovec, Rádovec), ki ne vsebujejo pripone -ina oz. -ica, so morali biti tvorjeni pred njunim nastopom, torej še v času dvočlenskih imen. Priponi sta torej nastopili v imenotvornem in ne apelativotvornem postopku. Ta spoznanja odpirajo etimološke možnosti nekaterim južnoslovanskim krajevnim imenom, ki doslej še niso bila zadovoljivo razložena. Ime Gámeljne (gámeljski, Gámeljc) je na osnovi srednjeveških zapisov in današnjega narečnega izgovora najprej rekonstruirano kot množinska oblika od *Gámljina, kar je razložljivo iz svojilnega pridevnika *Gäml'b osebnega imena *Gämb, ki se ohranja v sloven. priimku Gam in v patronimikih Gamič, hrv. Gamić in rus. Gámov. Imena glavnega mesta Kosova, ki se v srb. glasi Prî̌stina, zaradi pridevnika prištêvskī in stanovniškega imena Prištëvac ni mogoče niti izpeljevati iz slovanskega apelativa *pryščína, potrjenega $\mathrm{v}$ moravsko češ. prýščina 'izvir, poplavljeno mesto na polju', niti domnevati prevzema iz domnevnega praromunskega imena *Priştînă, kar naj bi se razvilo iz antičnega *Prisciāna, saj bi v obeh primerih pričakovali (1) konsolidirano imensko družino in (2) kratki padajoči naglas na ï $<$ î. Upoštevajoč tvorbeni model južnoslovanskih imen na -ina z nekonsolidiranimi imenskimi družinami je krajevno ime Prî̌tina najverjetneje tvorjeno iz svojilnega pridevnika naglasnega vzorca b nekega osebnega imena, morda slov. *Prišskb, ki se ohranja v kajk. priimku Prišsek in stpolj. osebnem imenu Przyszek (to je izvorno patronimična manjšalnica hipokoristika slov. osebnega imena * Pribyslavz), manj verjetno prevzetega iz lat. nomena gentile Prīscius ali prenomena Prīscus.

\section{Slovene Place Names with the Suffix -ina: Some Difficult Case and Implications for South Slavic Onomastics}

The paper treats Slovene and other South Slavic place and regional names with the suffix -ina, which include adjectives and ethnonyms in which the forms lack the suffix, e.g., Sln. Ljubéčna <*Ljubičina with the adjective ljubéški<*ljubiški and the ethnonym Ljubéčan < *Ljubícan, Cr. Hèrcegovina with the adjective hèrcegovački and the ethnonym Hèrcegovac. Such families of names have not yet been designated by a technical term in the literature; for this reason the term unconsolidated family of names is proposed. Though local and regional names with the suffix -ina in normal, consolidated families of names arise from appellatives, e.g., Dolina 'valley', Planína 'mountain', or are derived from personal names, e.g., Svétina, Bogojína, Krtína, Dragočájna, it appears that names ending in -ina from unconsolidated name families can only be derived from possessive adjectives from personal names, e.g., Ljubéčna 
$<{ }^{*}$ Ljubićina $<*$ Lubîtina from *Lubît'b, or words that characterize a person, e.g., Ajdovščina from ájd 'pagan'. It can thus be assumed with a high degree of certainty that such names arose through univerbization of bipartite nominal phrases of the type *Ljubića vás, *Ájdovska vás. In other words, they are derived from bases that were already parts of names, just as names ending in -ica with an adjectival base and an unconsolidated family arose by univerbization from a syntagm of the type *Rádova vás $>$ Rádovica.

The corresponding adjectives (ljubéški, ájdovski, rádovski) and ethnonyms (Ljubéčan, Ájdovec, Rádovec) without the suffixes -ina or -ica must have been created first, at a time when the bipartite structure was still in use. The suffixes therefore arose in the derivation of the name and not in the process of the formation of the appellative. This analysis gives us insight into the possible etymologies for certain South Slavic place names that have hitherto remained inadequately explained. The name Gámeljne (gámeljski, Gámeljc) on the basis of medieval attestations and today's dialectal pronunciation leads us to the reconstruction of a plural form from *Gámljina, which can be analyzed as a possessive adjective * Gäml'b derived from the personal name * ${ }^{*} a ̈ m$, which is preserved in the Slovene surname Gam and in the patronymic Gamič, Cr. Gamić and Rus. Gámov. The name of the capital of Kosovo, which in Serbian is pronounced Prî̌stina, cannot be derived-in light of the adjective prištêvskī and ethnonym Prištêvac-from the appellative *pryščína, which is otherwise attested in Moravian Cz. prýščina 'spring, flooded area in a field'. Nor is it possible to proceed from a hypothetical borrowing from Proto-Romanian *Priştînă, which might have developed from an ancient *Prisciāna, as we would in both instances expect (1) a consolidated family of names and (2) short falling stress on $\ddot{i}<$ í. In view of the derivational model of South Slavic names ending in -ina with an unconsolidated family the place name Prîstina most likely is derived from a possessive adjective with a b-paradigm stress pattern, perhaps Proto-Slavic * Prišsk $b$, as is preserved in the Kajkavian surname Prišek and the Old Polish personal name Przyszek (originally a patronymic diminutive hypochoristic of the Slavic personal name * Pribyslavb). It is less likely to have been borrowed from a Latin nomen gentile Prīscius or first name Prīscus. 


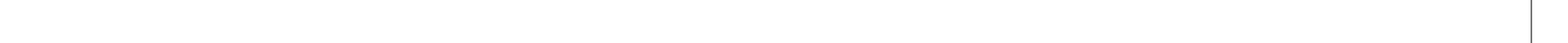

